\title{
Structure Design and Analysis for 110kV FRP Transmission Pole
}

\author{
Liqiang An \\ School of Energy, Power and Mechanical Engineering \\ North China Electric Power University, NCEPU \\ Baoding, China \\ e-mail: alq2146@163.com
}

\author{
Bo Yang \\ School of Energy, Power and Mechanical Engineering \\ North China Electric Power University, NCEPU \\ Baoding, China \\ e-mail: hdyb2009@sina.cn
}

\begin{abstract}
As an important class of special load-bearing structure, transmission pole affects the security, economy and reliability of transmission lines running directly. With the implementation of domestic major projects in recent years, such as UHV project, smart grid and transformation of rural grid, transmission pole of composite materials (referring to fiberglass reinforced composites in this paper) becomes one focus of attention in electric power industry for its lightweight, high strength, good electrical insulation, easy maintenance and good environmental adaptability, etc. Based on the existing national code for design of overhead transmission lines, design requirements, research and engineering practical experience, the structure design of a $110 \mathrm{kV}$ FRP pole is completed in the paper. Subsequently, the problem of small elastic modulus and large deflection are solved by mainly considering the pole's structure, material and cross section, etc. Then, the finite element static analysis is carried out in ANS YS. Result shows that the transmission pole meets the requirements of stress and deflection in the national code, which provides a theoretical reference for a further research.
\end{abstract}

Keywords-FRP; 110k Vtransmission pole; Structure design; Finite element static analysis.

\section{INTRODUCTION}

As an important load-bearing structure of overhead transmission lines, the present materials of transmission pole are mainly steel, concrete and wood. It is reported that, the traditional pole of steel, concrete or wood commonly has many defects, such as large quality and power loss, being easy to be corrosive and cracking, being hard and be expensive of transportation, construction and maintenance ${ }^{[1]}$, which consumes a lot of mineral resources and destroys environment. So FRP (Fiberglass Reinforced Plastic) transmission pole becomes one focus of attention in electric power industry and has made a significant progress in a nu mber of domestic research applications ${ }^{[2]}$, as a lowcarbon, energy-saving, environmentally friendly and new structures meeting the technical aesthetics for its lightweight, high strength, good electrical insulation, easy maintenance and good environmental adaptability, etc.

China has started research on composite transmission structure since the $1950 \mathrm{~s}$, but failed to pro mote application for the limit to material properties and technological level ${ }^{[3]}$. In recent years, especially since 2009 , the State Grid has begun to promote the construction of resource-saving, environment-friendly, new technology, materials and technology transmission lines, with the improvements in manufacturing process and properties of fiber and resin materials. Subsequently, many domestic companies and research institutes start laboratory for exploration and research on composite transmission structure.

At present, pilot projects of FRP transmission structure at voltage level of $110 \mathrm{kV}, 220 \mathrm{kV}, 500 \mathrm{kV}$ and $750 \mathrm{kV}$ are running in China ${ }^{[4]}$. Wherein, those of $220 \mathrm{kV}$ and below are commonly single-rod or lattice, but for a higher voltage level or heavier load line, adopt partial insulating of FRP cross-arm. Subsequently, latticed structures made from FRP have gradually attracted many attentions ${ }^{[5]}$.

However, there is no national or industry technical code of FRP transmission structure published in China, the paper will solve the problem of small elastic modulus and large deflection of the FRP transmission pole by considering to optimize material and cross section, etc., basing on the existing national code for design of overhead transmission lines, design requirements, research and engineering practical experience. Then, complete the design for $110 \mathrm{kV}$ FRP transmission pole and summarize the is sues to consider for a further study in the design by finite element static analysis.

\section{DESIGN FOR $110 \mathrm{kV}$ FRP POLE}

\section{A. Design Parameters}

\section{1) Design Requirements}

a) Environment:

meteorological conditions: typical region VI

altitude: less than $1000 \mathrm{~m}$

contamination level: class III

terrain: plains.

b) Voltage level and nu mber of loops: $110 \mathrm{kV}$, doubleloop.

c) Conductor: LGJ240/30, Ground: JL/LB1A-95/55.

d) Design span: horizontal span $l_{\mathrm{h}}=200 \mathrm{~m}$, vertical $\operatorname{span} l_{\mathrm{v}}=250 \mathrm{~m}$.

e) Weather conditions: maximum wind velocity $V_{\max }=25 \mathrm{~m} / \mathrm{s}$, ice thickness $\delta=10 \mathrm{~mm}$, the highest temperature $t=40^{\circ} \mathrm{C}$.

f) The main pole adopts FRP. 
2) Design Parameters

According to the conductor and ground type in design requirements above, the design parameters of them are found or calculated, and listed in the following Table I .

TABLE I. PARAMETERS OF CONDUCTOR AND GROUND

\begin{tabular}{lll}
\hline \multicolumn{1}{c}{ Design Parameter } & Conductor & \multicolumn{1}{c}{ Ground } \\
\hline Calculated sectional area $A\left(\mathrm{~mm}^{2}\right)$ & 275.95 & 100.88 \\
Diameter $d(\mathrm{~mm})$ & 21.60 & 12.48 \\
Linear elastic coefficient $E(\mathrm{MPa})$ & 73000 & 103600 \\
Thermal expansion coefficient $\alpha\left(1 /{ }^{\circ} \mathrm{C}\right)$ & $19.6 \times 10^{-6}$ & $15.5 \times 10^{-6}$ \\
Tensile strength $\sigma_{\mathrm{p}}(\mathrm{MPa})$ & 260.324 & 612.014 \\
Safety coefficient $k$ & 2.5 & 3 \\
Calculated tensile force $(\mathrm{N})$ & 75620 & 61740 \\
Allowable stress $\left[\sigma_{0}\right](\mathrm{MPa})$ & 104.13 & 204.005 \\
Annual operational stresses $\left[\sigma_{\mathrm{cp}}\right](\mathrm{MPa})$ & 65.08 & 153.003 \\
Nominal weight per km $(\mathrm{kg} / \mathrm{km})$ & 922.2 & 474.6 \\
\hline
\end{tabular}

According to the design requirements above and design parameters in Table I, the unit-load (means unit-length \& unit-area weight) of conductor and ground is calculated in the following Table II.

TABLE II. UNIT-LOAD OF CONDUCTOR AND GROUND

\begin{tabular}{|c|c|c|c|}
\hline Unit-load category & $\left(10^{-3} \mathrm{MPa} / \mathrm{m}\right)$ & Conductor & Ground \\
\hline Own weight load & $\gamma_{1}(0,0)$ & 32.75 & 46.14 \\
\hline Icing weight load & $\gamma_{2}(10,0)$ & 31.75 & 61.79 \\
\hline Vertical total load & $\gamma_{3}(10,0)$ & 64.50 & 107.93 \\
\hline \multirow{5}{*}{ No icing wind load } & $\gamma_{4}(0,10)$ & 5.38 & 9.28 \\
\hline & $\gamma_{4}(0,15)$ & 9.08 & 15.67 \\
\hline & $\gamma_{4}(0,25)^{*}$ & 28.59 & 49.29 \\
\hline & $\gamma_{4}(0,25)^{* *}$ & 20.52 & 35.37 \\
\hline & $\gamma_{4}(0,5)$ & 1.01 & 1.74 \\
\hline Icing wind load & $\gamma_{5}(10,10)$ & 10.36 & 22.14 \\
\hline \multirow{4}{*}{ No icing complex load } & $\gamma_{6}(0,10)$ & 33.19 & 47.06 \\
\hline & $\gamma_{6}(0,25)^{*}$ & 43.47 & 67.52 \\
\hline & $\gamma_{6}(0,25)^{* *}$ & 38.65 & 58.14 \\
\hline & $\gamma_{6}(0,5)$ & 32.77 & 46.17 \\
\hline Icing complex load & $\gamma_{7}(10,10)$ & 65.33 & 110.18 \\
\hline
\end{tabular}

\section{B. Structure Design}

\section{1) Calculate the Maximum Sag}

Those may be the control meteorological conditions are the lowest temperature, maximum wind, icing wind and annual average temperature. Because maximum wind and icing wind are of the same temperature and allowable stress, the one has smaller unit-load can not be the control meteorological condition. Therefore, maximu m wind is no longer possible to be the control meteorological condition, according to Table II . Comparison of the other three meteorological conditions is in Table III.
TABLE III. COMPARISON OF METEOROLOGY

\begin{tabular}{cccc}
\hline Meteorology & $\begin{array}{c}\text { The Lowest } \\
\text { Temperature }\end{array}$ & Icing Wind & $\begin{array}{c}\text { Annual Average } \\
\text { Temperature }\end{array}$ \\
\hline$\left[\sigma_{0}\right](\mathrm{MPa})$ & 104.13 & 104.13 & 65.08 \\
$t\left({ }^{\circ} \mathrm{C}\right)$ & -20 & -5 & 10 \\
$\gamma\left(\times 10^{-3} \mathrm{MPa} / \mathrm{m}\right)$ & 32.75 & 65.33 & 32.75 \\
$\gamma /\left[\sigma_{0}\right]\left(\times 10^{-3} / \mathrm{m}\right)$ & 0.3145 & 0.6274 & 0.5032 \\
Number* & $\mathrm{a}$ & $\mathrm{c}$ & $\mathrm{b}$ \\
\hline \multicolumn{4}{c}{ Notes: $*$ Number of $\gamma /\left[\sigma_{0}\right]$ from small to large }
\end{tabular}

Critical span is calculated as follows:

$$
l_{i j}=\sqrt{\frac{24\left[\left[\sigma_{0}\right]_{j}-\left[\sigma_{0}\right]_{i}+\alpha E \cos \beta\left(t_{j}-t_{i}\right)\right]}{E\left[\left(\frac{\gamma_{j}}{\left[\sigma_{0}\right]_{j}}\right)^{2}-\left(\frac{\gamma_{i}}{\left[\sigma_{0}\right]_{i}}\right)^{2}\right] \cos ^{3} \beta}}
$$

Assuming no elevation, $\cos \beta=0$. The data in Table III into the Formula (1), critical spans are calculated in the following Table IV.

TABLE IV. DISTINGUISH OF EFFECTIVE CRITICAL SPAN

\begin{tabular}{c|c|c|c}
\hline $\begin{array}{c}\text { Control } \\
\text { conditions }\end{array}$ & $\begin{array}{c}\text { a (The lowest } \\
\text { temperature) }\end{array}$ & $\begin{array}{c}\text { b Annual average } \\
\text { temperature) }\end{array}$ & c (Icing wind) \\
\hline \multirow{2}{*}{ Critical span } & $\begin{array}{c}l_{\mathrm{ab}}=90.8 \mathrm{~m} \\
l_{\mathrm{ac}}=154.7 \mathrm{~m}\end{array}$ & $l_{\mathrm{bc}}=202.9 \mathrm{~m}$ & - \\
\hline
\end{tabular}

The Table IV above shows, $l_{\mathrm{ab}}=90.8 \mathrm{~m}$ and $l_{\mathrm{bc}}=202.9 \mathrm{~m}$ are effective critical spans. So the lowest temperature will be the control condition at horizontal span $l_{\mathrm{h}}<l_{\mathrm{ab}}$, annual average temperature at $l_{\mathrm{ab}}<l_{\mathrm{h}}<l_{\mathrm{bc}}$, and icing wind at $l_{\mathrm{h}}>l_{\mathrm{bc}}$. Apparently, annual average temperature is the control meteorological condition in this paper.

Calculate the stress $\sigma_{0}$ and sag $f$ under unknown conditions of the highest temperature, external overvoltage no wind, and icing no wind using the following state equation, with annual average temperature known. Stress $\sigma_{0}$ and sag $f$ underdifferent spans are listed in Table $\mathrm{V}$.

State equation:

$\sigma_{c 2}-\frac{E \gamma_{2}^{2} l^{2}}{24 \sigma_{c 2}^{2}}=\sigma_{c 1}-\frac{E \gamma_{1}^{2} l^{2}}{24 \sigma_{c 1}^{2}}-\alpha E\left(t_{2}-t_{1}\right)$

Sag equation:

$f=\frac{\gamma_{0} l^{2}}{8 \sigma_{0}}$ 
TABLE V. STRESS $\sigma_{0}$ AND SAG $f$ UNDER DIFFERENT SPANS

\begin{tabular}{cccccccc}
\hline \multirow{2}{*}{$\begin{array}{c}\text { Span } \\
(\mathbf{m})\end{array}$} & \multicolumn{2}{c}{ The highest } & \multicolumn{2}{c}{ External overvoltage } & \multicolumn{2}{c}{ Icing no wind } \\
& $\boldsymbol{\sigma}_{\mathbf{0}}(\mathbf{M P a})$ & $\boldsymbol{f}(\mathbf{m})$ & $\boldsymbol{\sigma}_{\mathbf{0}}(\mathbf{M P a})$ & $\boldsymbol{f}(\mathbf{m})$ & $\boldsymbol{\sigma}_{\mathbf{0}}(\mathbf{M P a})$ & $\boldsymbol{f}(\mathbf{m})$ \\
\hline 100 & 44.35 & 0.92 & 70.17 & 0.58 & 103.88 & 0.78 \\
150 & 46.60 & 1.98 & 65.62 & 1.40 & 103.68 & 1.75 \\
200 & 48.15 & 3.40 & 61.80 & 2.65 & 103.50 & 3.12 \\
202.9 & 48.22 & 3.50 & 61.61 & 2.74 & 103.49 & 3.21 \\
250 & 51.35 & 4.98 & 62.31 & 4.11 & 107.21 & 4.70 \\
300 & 53.90 & 6.84 & 62.87 & 5.86 & 110.50 & 6.57 \\
350 & 55.86 & 8.98 & 63.30 & 7.92 & 113.19 & 8.73 \\
400 & 57.39 & 11.41 & 63.63 & 10.29 & 115.38 & 11.18 \\
\hline
\end{tabular}

Results show that the maximum sag $f=3.5 \mathrm{~m}$ occurs at the highest temperature conditions.

\section{2) Material and Dimension Design}

Transmission pole generally adopts resin-based composite materials, mainly composed of resin and reinforcing fibers, and the reinforcing fibers commonly is fiberglass.

In order to prevent conductor cross-arm from bending and narrowing the safety gap excessively, foam-filled hollow tube is used for cross-arm to improve its flexural rigidity, which makes up for its deficiencies of small elastic modulus and large deflection effectively ${ }^{[6]}$. And increase FRP insulators rods, which is fixed to the pole via metal hoops ${ }^{[7,8]}$. Meanwhile, to prevent pollution and lightning flashover, silicone rubber sheath dressing with sheds is added to the hollow FRP tube, which will enhance the creepage distance of FRP cross-arm effectively.

For the main pole, use an all-composite tapered tube rod, which is fixed to the foundation anchor bolts by a metal sleeve flange. To make up for the difference of expansion coefficient between FRP and steel, adopt resincasting flexible-connection techniques or structural adhesive between the metal sleeve flange and the FRP pole.

According to the literature ${ }^{[9]}$, and referencing the dimensions of a double-loop FRP test pole in Panzi, Shenzhen, its top diameter of the preliminary design is $500 \mathrm{~mm}$, the root diameter is $700 \mathrm{~mm}$ and the thickness is $20 \mathrm{~mm}$, and cancel suspension insulator strings. Dimensions of pole head are shown in Fig. 1.

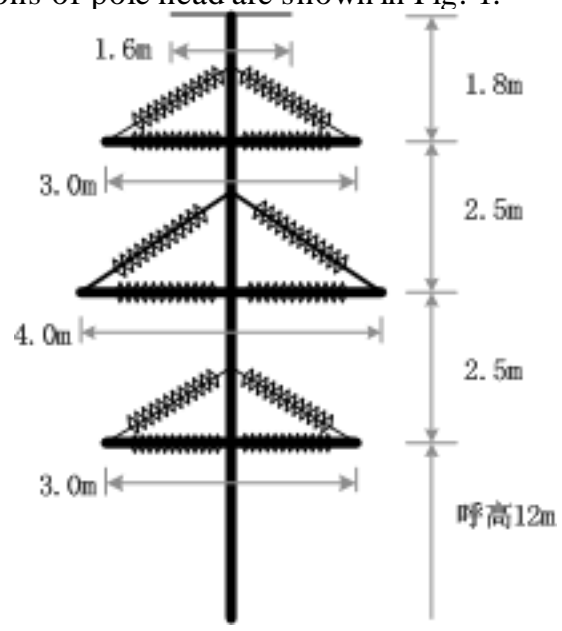

Figure 1. FRP pole head dimensions.

\section{3) Main Pole Cross-section}

For a single all-composite pole, in order to increase its flexural rigidity, it is necessary to design a reasonable cross-section or rib inside, to obtain a maximum moment of inertia for the same cross-sectional area. According to the literature ${ }^{[10]}$, three main forms of cross-section are shown in Fig. 2. A mong them, the triangular rib structure is superior to the others not only in terms of deformation but also stress. Therefore, choose the cross-section with triangular rib.

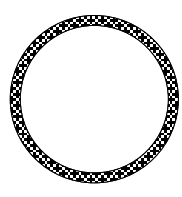

(a)Thin wall ring

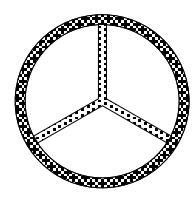

(b)ring with star rib (c)ring with triangular rib
Figure 2. FRP pole cross-section.

\section{STATIC ANALYSIS}

\section{A. Finite Element Modeling}

As it is shown in Fig. 3, o mit the cross-arm insulator sheds and pull rods, build the ground support, FRP cross arm and the main pole as a whole model using SHELL99 element, since that stress and deformation of the main pole is mainly studied in the paper. And basic structure parameters of FRP are listed in the following Table VI, according to the literature ${ }^{[11]}$.

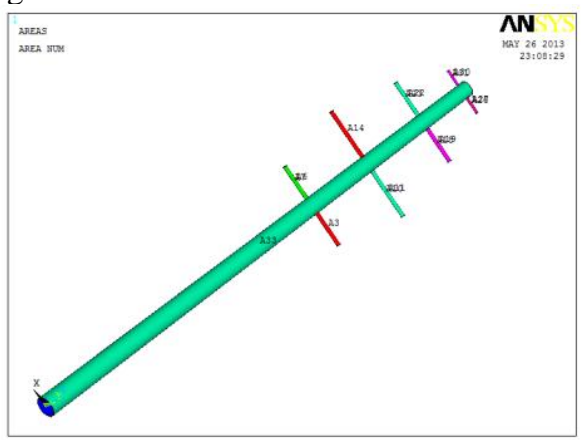

Figure 3. FRP pole finite element modeling.

TABLE VI. BASIC STRUCTURE PARAMETERS OF FRP.

\begin{tabular}{lc}
\hline \multicolumn{1}{c}{ Structure Parameter } & Parameter Value \\
\hline$E_{\mathrm{X}}(\mathrm{GPa})$ & 39.8 \\
$E_{\mathrm{Y}}(\mathrm{GPa})$ & 8.4 \\
$E_{\mathrm{Z}}(\mathrm{GPa})$ & 8.4 \\
$\mu_{\mathrm{XY}}$ & 0.25 \\
$\mu_{\mathrm{XZ}}$ & 0.25 \\
$\mu_{\mathrm{YZ}}$ & 0.25 \\
$G_{\mathrm{XY}}(\mathrm{GPa})$ & 4.2 \\
$G_{\mathrm{XZ}}(\mathrm{GPa})$ & 4.2 \\
$G_{\mathrm{YZ}}(\mathrm{GPa})$ & 4.2 \\
\hline
\end{tabular}

\section{B. Design of Ply Packing}

The total ply numbers, thickness and orientation angle of each ply are shown in Table VII, divid ing into three parts such as the main pole, cross-arm and ground support. Fig. 4 is the symmetrical ply packing of the main pole. 
TABLE VII. Ply PACKING PARAMETERS OF FRP.

\begin{tabular}{cccl}
\hline Structure & Numbers & Thickness & Orientation Angle $\left(^{\circ}\right)$ \\
\hline Main pole & 10 & 2 & $\begin{array}{l}0 / 45 / 0 /-45 / 0 / 0 /- \\
45 / 0 / 45 / 0\end{array}$ \\
& & & $0 / 45 / 0 /-45 / 0 / 0 /-$ \\
Cross-arm & 10 & 1 & $45 / 0 / 45 / 0$ \\
Ground support & 7 & 1 & $0 / 45 / 0 /-45 / 0 / 45 / 0$ \\
\hline
\end{tabular}

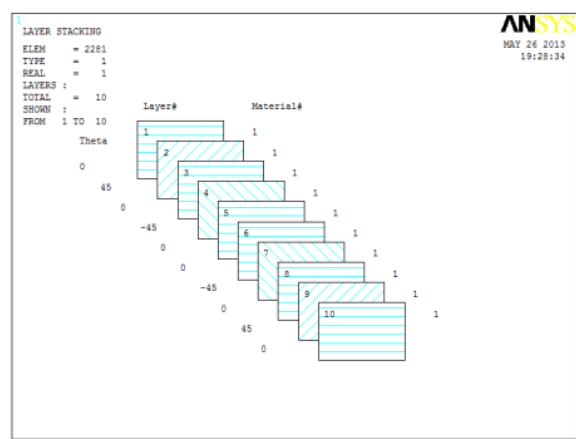

Figure 4. ply packing of the main pole.

\section{Load Calculation}

Whether the external loads combination on the pole is reasonable directly affects its safety and economy. According to GB 50545-2010 "Code for designing of $110 \sim 750 \mathrm{kV}$ overhead transmission line", the working conditions of operation, disconnection, installation and special load must be considered in the strength calculation and analysis.

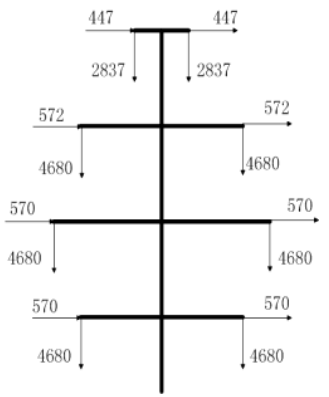

(a)

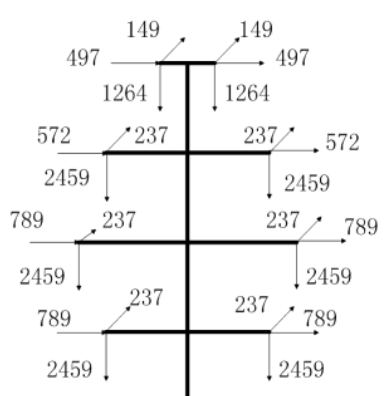

(c)

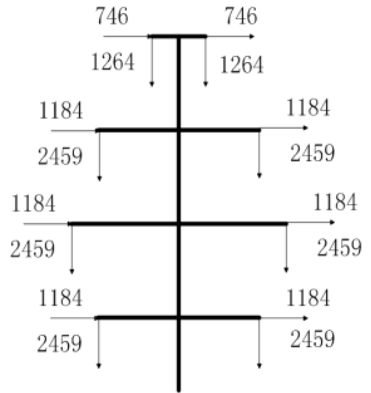

(b)

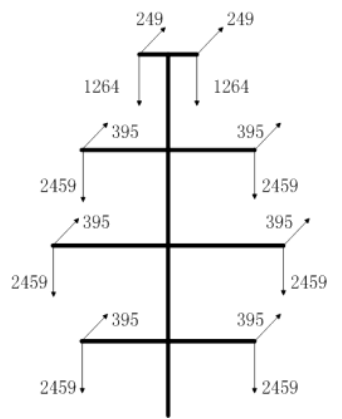

(d)

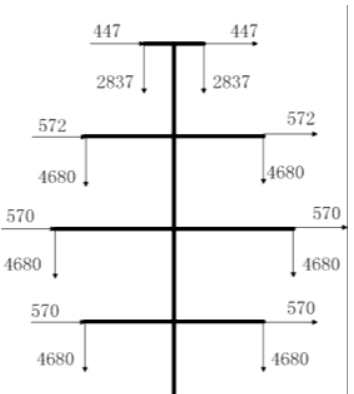

(e)

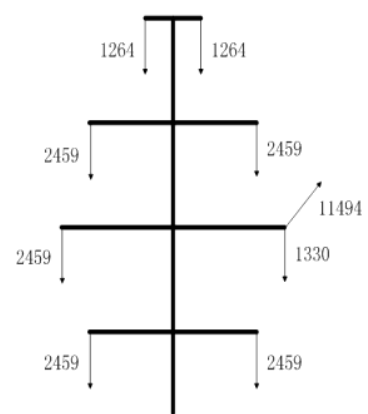

(g)

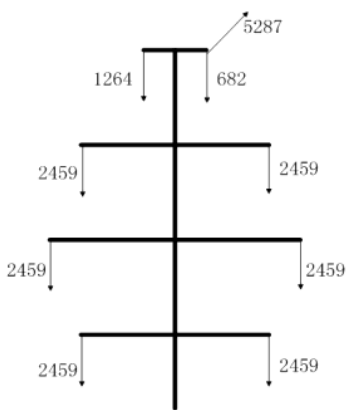

(i)

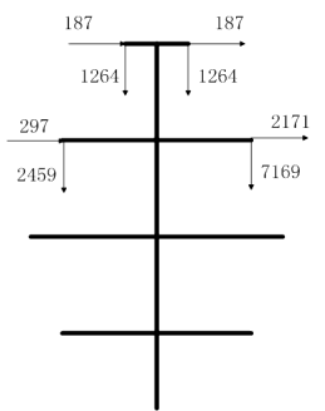

(k)

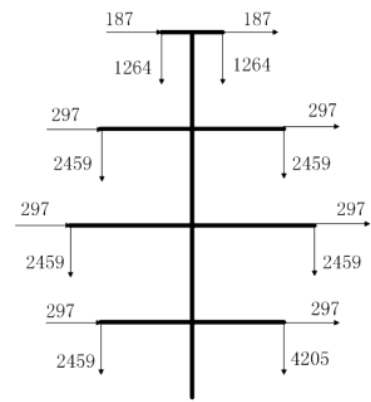

(m)

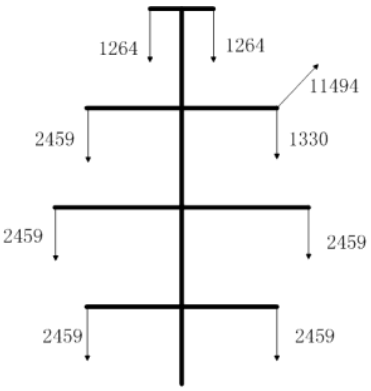

(f)

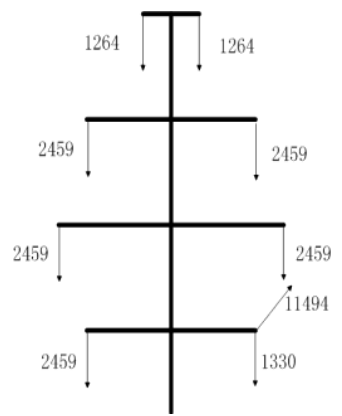

(h)

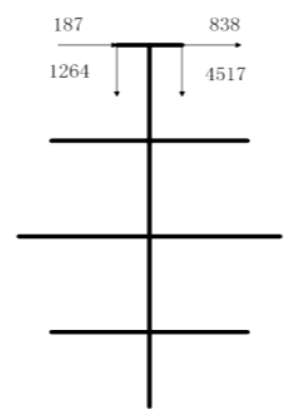

(j)

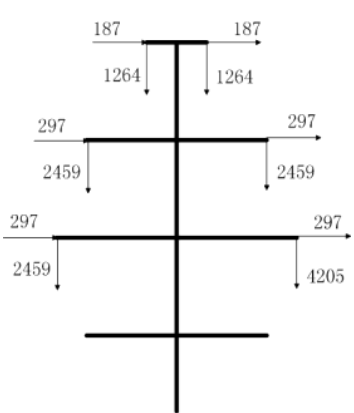

(l)

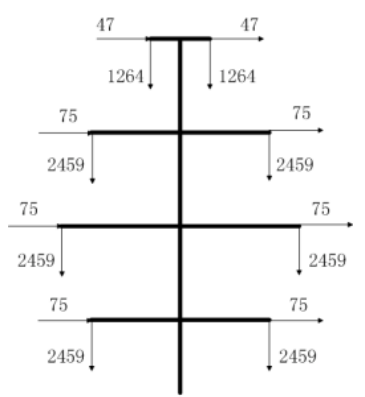

(n)

(a-d) Operating conditions $\mathrm{I}\left(90^{\circ}, 60^{\circ}, 45^{\circ}\right.$ and $0^{\circ}$ wind); (e) Operating conditions II ; ( $\sim$ i) One upper, middle, lower conductor, and ground disconnected (j-m) One ground, and upper, middle, lower conductor installed (n) Loads long-term effects

Figure 5. External load on the pole head 


\section{Analysis of Results}

Apply the boundary and loads to the FRP pole, and calculate the working conditions of loads combinations in Fig. 5. Displacement contour in the $60^{\circ}$ maximum wind condition is shown in Fig. 5. In order to analyze the internal forces and deformation of the main pole, a list of its maximum node stress and displacement is output in the following table VIII.

TABLE VIII. MAXIMUM NODE STRESS AND DISPLACEMENT OF THE MAIN POLE.

\begin{tabular}{|c|c|c|c|c|}
\hline Worki & g Conditions & $\begin{array}{l}\text { Stress } \\
\text { (MPa) }\end{array}$ & $\begin{array}{l}\text { Displace - } \\
\text { ment }\end{array}$ & $\begin{array}{l}\text { Deflec } \\
\text {-tion }\end{array}$ \\
\hline & $0^{\circ} \max$ wind & 36.08 & 129.89 & $0.68 \%$ \\
\hline Operating & $45^{\circ} \max$ wind & 36.88 & 351.36 & $1.85 \%$ \\
\hline conditions I & $60^{\circ} \max$ wind & 37.16 & 531.67 & $2.80 \%$ \\
\hline & $90^{\circ} \max$ wind & 37.63 & 708.41 & $3.73 \%$ \\
\hline $\begin{array}{c}\text { Operating } \\
\text { conditions II }\end{array}$ & The thickest ice & 69.60 & 272.67 & $1.44 \%$ \\
\hline & $\begin{array}{l}\text { One upper conductor } \\
\text { disconnected }\end{array}$ & 83.97 & 627.56 & $3.30 \%$ \\
\hline Accident & $\begin{array}{l}\text { One middle } \\
\text { conductor } \\
\text { disconnected }\end{array}$ & 135.25 & 472.83 & $2.49 \%$ \\
\hline & $\begin{array}{l}\text { One lower conductor } \\
\text { disconnected }\end{array}$ & 92.37 & 331.09 & $1.74 \%$ \\
\hline & $\begin{array}{l}\text { One ground } \\
\text { disconnected }\end{array}$ & 48.78 & 341.11 & $1.80 \%$ \\
\hline & $\begin{array}{l}\text { One upper conductor } \\
\text { installed }\end{array}$ & 70.35 & 268.87 & $1.42 \%$ \\
\hline Installation & $\begin{array}{c}\text { One middle } \\
\text { conductor installed }\end{array}$ & 63.34 & 239.39 & $1.26 \%$ \\
\hline & $\begin{array}{l}\text { One lower conductor } \\
\text { installed }\end{array}$ & 36.13 & 223.41 & $1.18 \%$ \\
\hline & One ground installed & 69.60 & 111.00 & $0.58 \%$ \\
\hline Loads 1 & g-term effects & 35.85 & 34.05 & $0.18 \%$ \\
\hline
\end{tabular}

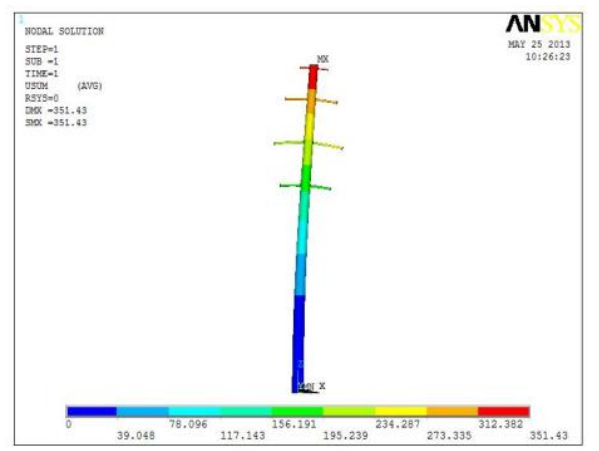

Figure 6. Displacement contour in $60^{\circ}$ max-wind condition.

According to the current national code for designing of overhead transmission line ${ }^{[12]}$, the maximum deflection of the pole must not exceed 5\% in the operating condition of loads long-term effects (wind velocity $v=5 \mathrm{~m} / \mathrm{s}$, ice thickness $b=0$ ). And Table VIII shows that the maximum node displacement of the $110 \mathrm{kV}$ FRP pole designed is $34.046 \mathrm{~mm}$ in the condition of loads long-term effects, that is deflection of $1.79 \%$, which meets the requirements of the national code above.

In addition, the maximu mode stress of the main pole is $152 \mathrm{MPa}$, which is far less than the FRP strength values listed in the following Table IX ${ }^{[11]}$, so its design strength also meets the design requirements.
TABLE IX. BASIC PERFORMANCE PARAMETERS OF FRP

\begin{tabular}{cc}
\hline Basic Performance Parameter & Parameter Value \\
\hline$\sigma_{\mathrm{X}+}(\mathrm{MPa})$ & 1130 \\
$\sigma_{\mathrm{X}-}(\mathrm{MPa})$ & 612 \\
$\sigma_{\mathrm{Y}+}(\mathrm{MPa})$ & 36.7 \\
$\sigma_{\mathrm{Y}-}(\mathrm{MPa})$ & 0.25 \\
$\tau_{\mathrm{XY}}(\mathrm{MPa})$ & 0.25 \\
\hline
\end{tabular}

\section{CONCLUSION}

Based on the existing national code for designing of overhead transmission line, design requirements, research and engineering practical experience, the structural design of a $110 \mathrm{kV}$ FRP pole is completed in the paper. And the problem of small elastic modulus and large deflection are solved by mainly considering the transmission pole's structure, material and cross section, etc. Finally, the finite element static analysis is carried out in ANSYS, results show:

(1)The maximum node displacement of the $110 \mathrm{kV}$ FRP pole is $34.046 \mathrm{~mm}$ in the condition of loads long-term effects, that is deflection of $1.79 \%$, which meets the requirements of $5 \%$ in the national code.

(2)The maximum node stress of the main pole is $152 \mathrm{MPa}$, which is far less than the FRP strength values, so its design strength also meets the design requirements.

In conclusion, studies show that the FRP transmission pole meets the requirements of stress and deflection in the existing national code, which provides a theoretical reference for a further research.

\section{ACKNOWLEDGEMENT}

This research was supported by Hebei Province Natural Science Foundation (E2013502291).

\section{REFERENCES}

[1] Ibrahim S, Polyzois D, Hassan S K. "Development of glass fiber reinforced plastic poles for transmission and distribution lines." Canadian Journal of Civil Engineering 27.5 (2000): 850-858.

[2] Hota G, Liang R. "Advanced fiber reinforced polymer composites for sustainable civil infrastructures." Proceedings of the International Symposium on Innovation \& Sustainability of Structures in Civil Engineering. 2011.

[3] Zhang L, Sun Q, Wang H C, et al. "Experimental study on the mechanical properties of E-glass fiber/epoxy composite material." Electric Power Construction/ Dianli Jianshe 31.9 (2010): 118-121.

[4] L.Quan, R. Zong-dong, and M. Zeng-lu. "The research of FRP applied in the transmission tower." Fiber Reinforced Plasticsl (2012): 012

[5] Polyzois D J, Raftoyiannis I G, Ochonski A. Experimental and analytical study of latticed structures made from FRP composite materials. Composite Structures, 2012.

[6] Fam, Amir, and Je-Kuk Son. "Finite element modeling of hollow and concrete-filled fiber composite tubes in flexure: Optimization of partial filling and a design method for poles." Engineering Structures 30.10(2008): 2667-2676.

[7] Li H, Deng S, Wei Q, et al. "Research on composite material towers used in $110 \mathrm{kV}$ overhead transmission lines." High Voltage Engineering and Application (ICHVE), 2010 International Conference on. IEEE, 2010.

[8] Zhang L, Sun Q, Zhao X, et al. "Material selection for transmission tower made of fiber reinforced plastics." Electric Power Construction/Dianli Jianshe 32.2 (2011): 1-5.

[9] Gong J, Zhang E M, Chen Y H, et al. "Structure design for $110 \mathrm{kV}$ FRP pole." East China Electric Power 40.9 (2012): 1557-1560. 
[10] Gong J, Zhang E, Cao S, et al. "Design of $110 \mathrm{kV}$ high performance fiber reinforced composite material transmission poles and towers." Water Resources and Power 30 (2012): 161-163.

[11] G.L. Shen, G. Hu. "Mechanics of composite materials". T singhua University Press, 2006.
[12] China Electricity Council. "GB 50545-2010, Code for designing of $110 \sim 750 \mathrm{kV}$ overhead transmission line.”. China Planning Press, 2010 . 